Angela Škovierová

Univerzitná knižnica v Bratislave

Ústav cudzích jayzkov LFUK v Bratislave

angela.skovierova@post.sk

ORCID 0000-0003-1522-9863

http://doi.org/10.33077/zbkh.2018.12.skovierova

\title{
Slovak humanist Ondrej Rochotský (ca. 1583-1623) and his works stored in the Wrocław University Library
}

\begin{abstract}
Humanist poet Ondrej Rochotský (Andreas Rochotius) belongs to the relatively large group of Slovak humanist writers who lived and worked outside Slovakia and their relationship to Slovakia is only reflected in their work. His literary work (two theatre plays, professional literature, reflexive poetry and amount of congratulations, condolences and other occasional verses) as well as relationships with others, especially Czech humanistic writers, are very rich. His relationship with the Czech nobleman Karel the Elder from Žerotín (Karel starší so Žerotína) is particularly significant. This is probably the time of Karel's stay in Wrocław in the years 1628-1633, when the Wrocław's University Library (WUL; Biblioteka Uniwersytecka we Wrocławiu) received and have been storing convolute with a few printed works of O. Rochotský, with his handwritten dedication inside. The aim of the paper is to clarify literary activities of O. Rochotský, to analyse his personality at the background of the social, cultural and political context of the first three decades of the $17^{\text {th }}$ century and to discuss in brief Rochotský works found in the WUL.
\end{abstract}

Key words: Ondrej Rochotský (Andreas Rochotius) - Karel the Elder from Žerotín (Karel starší so Žerotína) - occasional works - poetry - humanism- old prints - Wrocław University Library.

Ondrej Rochotský (Andreas Rochotius) was a contemporary of the group of the Slovak humanists whose works reconnected with the Czech lands, or rather Prague ${ }^{1}$. According to German databases he came from Ober Rochlitz (now Rokytnice nad Jizerou) in northeastern Bohemia, but he is bound to

A. Škovierová, Jesseniovi slovenski súčasnici v Čechách. Vzájomné vzt’ahy a kultúrne súvislosti, [in:] Ján Jessenius (1566-1621) L’udia a doba. Medzinárodná vedecká konferencia konaná 8. decembra 2016, ed. M. Gogola, L. Rybár, Bratislava 2017, Historia Medicinae Slovaca, 1, pp. 72-92. 
this town only by the epithet „from Rochicerperk” (a Rochicerberga, a Rochiczerberga, a Rochiczerperga), which he most probably acquired in 1607. His actual birthplace (ca. 1583) is Nemecká L'upča (now Partizánska L’upča) in Slovakia, in the district of Liptovský Mikuláš. He was a poet, playwriter, specialist writer, and teacher. He worked in several town schools in Bohemia. As early as 1602-1604, his work at a school in Prague's Malá Strana is mentioned. In the years 1604-1605 he worked at a school in Dvor Králové nad Labem. Between 1607 and 1608 he worked in Prostějov, and in 16091610 he was a private teacher in Jaroslav Kaplír's house (an aristocrat from Sulevice and in Č́žkov). In 1611 he was named administrator of the school in Chrudim, where he did not even stay for a full year - he started working in Hradec Králové between 1611 and 1612. However, it seems he was not successful here either, as Jan Hubecius, the senator of the city Hradec Králové, asked Martin Bacháček, the rector of the Charles University in Prague, for a better administrator after a few months ${ }^{2}$.

The number of preserved works reveals that $\mathrm{O}$. Rochotský was among the most productive Slovak humanist poets working in Bohemia and Moravia. He self-published several collections of occasional, festive, congratulatory and condolence poetry ${ }^{3}$. He poetically adapted biblical themes as well as important historical events. However, the end of Rochotsky's life is covered with mystery. We know that he returned to Chrudim where he married the daughter of a local soap-maker Daniel in 1612 or 1613 and became a burgher and affluent local. His first marriage did not last long because on March $24^{\text {th }}$ 1614 he married Anna Zuzana (surname unknown) and in that same year his only son, Samuel, was born. There are no confirmed accounts of his life after this point, neither about his death. He is said to had lived in Chrudim until $1622^{4}$ and died in $1623^{5}$.

On November $8^{\text {th }} 1620$, in midst of The Thirty Years' War and The Czech Estates Uprising, a battle between the Czech estates and the Catholic League took place on the White Mountain near Prague. The victory of the Habsburg troops meant that King Ferdinand II had begun to implement a vigorous

Z. Wintr, Život a učení na partikulárních školách v Čechách a XV. a XVI. století, Praha 1901, p. 183.

Slovenský biografický slovník od roku 833 do roku 1990. Vol. 5: R-S, ed. V. Mináč, Martin 1992, p. 105. We have approached O. Rochotski's personality and work in several articles, see e.g. A. Škovierová: Humanistický básnik Ondrej Rochotský. Jeho život, činnost', dielo a vztahy ku Slovensku, „Kniha” 2007, pp. 223-233; Ondrej Rochotský a jeho literárna činnost’v kontexte tvorby slovenských humanistov v Čechách, „Kniha” 2012, pp. 133-145.

4 A. Truhlář, K. Hrdina, Rukovět’ k písemnictví humanistickému, zvláště básnickému v Čechách a na Moravě ve XVI. století, Praha 1918, p. 334.

5 P. Horváth, Humanisti z Českých krajín v pobelohorskom exile v Trenčine, „Historica” 1975, Vol. 26, p. 155. 
Counter-reformation policy. He issued religious mandates that affected various areas of religious, social or career life of non-Catholics, and caused a massive exodus of the country's population-emigration. The Czech and Moravian Protestants went to the nearest border countries, especially to Saxony, Lusatia, Silesia, Slovakia and Hungary ${ }^{6}$.

Although the greatest protector and the most important patron of O. Rochotský, Karel the Elder from Žerotín (Karel starší so Žerotína), was preserved from the persecutions after the White Mountain battle due to loyalty to Emperor Ferdinand ${ }^{7}$ during the uprising, he would still willingly emigrate after renewing the constituent ordinance to demonstrate and be an example, and to lift the spirits of the other exiles whilst also pointing out the violent recatholization policy of the Habsburgs in the Czech lands to the international circles. He lived in Wrocław from 1628 to 1633 where he continued to keep in touch with Protestant intellectuals (e.g. Jan Ámos Komenský), and also provided protection for them in his Moravian manors ${ }^{8}$. It is not known whether after these events, Rochotský still lived in Chrudim on Žerotin's land or if he went to Wrocław with his patron.

Karel from Žerotín, a well-educated humanist, also involved in leading position in Moravian land politics, hi was literally active and his work was politically motivated. He was also a political protector of the Unity of the Brethren and Jan Amos Komenský, and probably a patron, protector, and supporter of Protestant scholars and clergymen. The devotion of the poet O. Rochotský to the aristocrat is particularly noteworthy. In this period of blossoming humanist education, it was very fashionable and common to write poetry dedicated to loved ones or important personalities on various occasions (e.g. death, marriage, coronation ...). This was also a way of expressing and maintaining interpersonal relationships. The occasional verses of O. Rochotský reflect his relationships with his patrons, but also with other humanist authors. The poet tried, as it was widespread during this period, to get into good graces of leading Moravian noblemen. Rochotsky's occasional poetry, focused on existing or presumed benefactors, was published not only in separate collections, but Rochotsky's congratulatory, festive, and other verses dedicated to Karel from Žerotin (or his close relatives) were part of almost every Rochotsky's book published during this period.

A preserved collection of old prints in the Wrocław University Library (WUL; Biblioteka Uniwersytecka we Wrocławiu) includes several prints of

6 J. Daňhelka [and others], Dějiny české literatury. [Vol.] I, ed. J. Hrabák, Praha 1959, pp. 337-338.

7 Ibidem, p. 418.

8 Biografický slovník Slezka a severní Moravy : nová řada. Sešit 1 [vol. 13], ed. M. Myška, L. Dokoupil, Ostrava 2000, pp. 107-108. 
O. Rochotsky with the author's handwritten dedication on the title sheet. Dedication of Convolute, which contains five Rochotsky's works published between the years 1606 and 1612 in Prague (or without the place of printing and the date of issue) is not dated, but we think that this collection may come from a period of Karel from Žerotin's residence in Wrocław in 1628-1633. Following the typical humanist titulature of:

Ex Illustrissimis Heroi et Literatissimis maxime pio Sobrio D. D. CAROLO A ZIEROTINA libero baroni in Drzevohosticz Rossicz et Przerovii Rei litterariae Patrono benignissimo Mecaenati suo perpetua fide ac benevolentia colendissimo he adds his own dedication Hunc exfuccum genii et ingenii sui faetum, dedicatione superioris commediae quaesub augustissimo nomine sublimitatis suae lucernam subolevit promissum: Debita observatione gratitudinisque nomine augusto tam iusto quam ingenuo. Author ddd.

and an autograph which he then ends with a quatrain:

Quem si ei que mente

offertur acceptum senserit, suo

semine haud excidisse: erit

affatim in quo gaudeat?

Here as well as in the printed dedications, O. Rochotský emphasizes Žerotin's knowledge, kindness, care, and fairness. Dedication is one of the effective instruments to represent status (aristocratic, institutional, or intellectual), and it is also one of many illustrations of literary patronage ${ }^{10}$. By handing his work to honoured people or honoured community (e.g. to Žerotin or to the city council), the author of the dedication tried to secure not only his own benefit, but also a sort of defense and protection for the work itself. Dedications are an important proof showing that the author and the recipient have a relationship. Our subsequent research will try to identify that relationship. At the same time, we should not step back from examining the formalities of these dedications that provide many valuable data, e.g. the entire title of the dedicant and his address, the date and place of the poem's creation (or of an event) and last but not least, all the descriptions of the social status and the function that the author of the dedication held at the time of his writing ${ }^{11}$. Most of Rochotsky's poetry devoted to art benefactors is related to Karel from Žerotin, as shown in the next sections of this paper. The very prints stored

9 O. Rochotský, Iosephiados comaedia ex Genesis Lib. cap. 39., 40., 41., Pragae: typis Schumanianis, [1607-1608], [44] unnumbered p., 4, Wrocław University Library (WUL), sign. BU 395682 .

10 R. Šimůnek, Reprezentace české středověké šlechty, Praha 2013, pp. 316-326; V. Bůžek, Literární mecenát nižši šlechty v předbělohorských Čechách, [in:] Husitství-reformace - renesance. Sborník k 60. narozeninám Františka Šmahela, Praha 1994, pp. 830-843.

11 J. Pišna, Předmluvy a paratexty v českých tiscích druhé poloviny 16. století a jejich výzkum - poznámky k problematice, „Kniha” 2014, pp. 79-80. 
in the WUL are an excellent example of his relationships with art patrons, supporters, and friends.

The volume devoted to Karel from Žerotin contains in a half-leather binding, with decorations of the Renaissance character, five prints of O. Rochotský in addition to other works. The first from among Rochotský's works is the print issued in Prague for the new year 1607 or 1608. It is the Iosephiados... ${ }^{12}$ theatre play, which is a dramatized story about Joseph in Egypt, written in iambian trimeters, senarii, and octonarii. The play's ideological and artistic character was similar to his following play Gedeon... based on the Old Testament. At first sight, it condemned adultery as one of the greatest sins. The deeper meaning, however, reveals Joseph, the slave of Pharaoh's governor Putifar, who was able to resist the temptations of Putifar's wife Artemon, as a prototype of a persistent Protestant who would not be tempted by the vision of doubtful welfare. On the contrary, he endured in his moral values, believing in righteousness. The play is devoted to Karl of Liechtenstein „illustrissimo [...] Carolo and Lichtenstein et Nicolspurg [...]" - yet another nobleman whose favour Rochotsky hoped to win. The recommending poem (12 couplets) was written by magister Ján Campanus Vodňanský (1572-1612) who was later himself an author of a play based on Czech history (Bretislaus, 1614), and a keen supporter of drama performances at the Charles University.

In 1606 in Prague, probably during O. Rochotsky's stay at the school in Mala Strana, his biblical school play Gedeon... ${ }^{13}$ was published. The plot revolves around an Old Testament Judge Gedeon, who banished the Madians and liberated Jerusalem. The play in the contemporary context was an allegory showing recent events against the backdrop of a biblical story ${ }^{14}$ (as he also did in his epic about Samson).

In 1605 Turks raided Moravia, but Moravian troops under the command of Karel from Žerotín fended the attackers off and drove them up to the river Váh ${ }^{15}$. This was not their first attack at Moravia as the Turks together with the Tatars invaded Moravia already in 1599. They then destroyed a large part of Upper Hungary and entered the Wallachia region through Hrozenkov Pass. They pillaged the territory up to Uherský Brod, where the Moravian emergency military units stopped them. They drove the Turks back and slaughtered them around the Javorník area. O. Rochotský sees the parallel

\footnotetext{
12 O. Rochotský, Iosephiados..., op. cit.

13 O. Rochotský, Gedeon comoedia nova. Cum primis ad usum scholasticum et conditionem temporum accomodata pro noVa ComaeDIa [1606]..., Pragae: typis Schumanianis, [1606], [36] unnumbered p., $4^{\circ}$, WUL, sign. BU 395683.

14 A. Truhláŕ, K. Hrdina, Rukovět' k písemnictví humanistickému..., p. 335.

15 Turci na Moravě a turecké války, [online] http://historik.webgarden.cz/rubriky/hlavni-stranka/turci-na-morave-a-turecke-valky [accessed 25.08.2016].
} 
with the biblical story firstly in the seven-year period where one is threatened by hostile raids into the country he considers to be his homeland, but also between the biblical hero Gedeon himself and his benefactor Karel from Žerotin, who like Gedeon, drove the enemy from his homeland, and to whom he had dedicated an introductory poem. Under the family coat of arms start three couplets: Insignia ... familiae baronum a Zierotina, followed by 39 couplets - the dedication of the whole play to the family and a celebration of Žerotin's military success in the poem Arte et Marte illustriss [imo] ... baroni d. d. Carolo a Zierotina ...
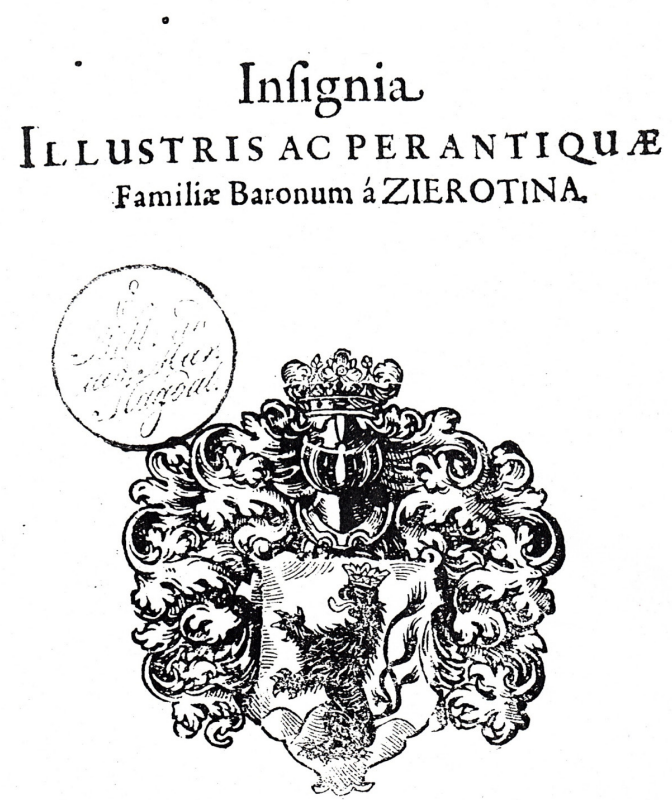

CVrLeo fublimifcopulo fe glorius effert 4 Signa Zierotinæ gentis avita gerens Robore quadrupedes quod ut hic fupereminet omnes Sic ea Marte,toga vincat \& Arte, pares. Illưfris longum ô gens îtis utere fignis, Altiusin coelum ut laude vehenda nova,

Phot. 1. Insignia ... familiae baronum a Zierotina... Source: O. Rochotský, Gedeon comoedia nova. Cum primis ad usum scholasticum et conditionem temporum accomodata pro noVa ComaeDIa [1606]..., Pragae: typis Schumanianis, [1606],

[36] unnumbered p., 4, WUL, sign. BU 395683 
The occasional lyrical poetry (congratulatory poems, epithalamia, and especially encomia and epicedia) prevailed over all genres of Latin humanist poetry ${ }^{16}$. When it comes to Latin occasional poetry, O. Rochotsky was a very prolific writer. Between 1606-1622 he wrote a vast number of Latin occasional poems (encomia, genethliaca, epithalamia, epicedia, and others). He published them mainly in his own compilations and they were part of almost all his printed works, but he also contributed to prints of various other humanists, such as to the following collections: $Г \lambda v \kappa \dot{\sigma} \sigma \varphi v \rho v o v$ anni supra sesquillesimum... 1607 (below $Г \lambda v \kappa \dot{\sigma} \sigma \varphi v \rho v o v)^{17}$, which represents an extensive collection of occasional poetry dedicated to benefactors from the ranks of nobility and burghers, but also relatives and friends. It aptly documented O. Rochotsky's connections to other humanists.

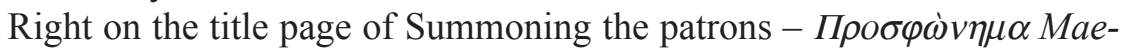
cenatum, which may be all the personalities mentioned in the collection, the author points out the importance of their support - Rochotský also points their attention to the poems he dedicated to them and wishes them a new year full of satisfaction (1607):

Illustris Artis Martisque decore Patroni

Quae foro ne vobis ne prohibete dari

\section{Vestris haec meritis quae dantur, debita dantur}

Nata quod in vestro quantu lacimque Solo

Nomine sub vestro proprie subolere lucernam

Hac meruere novum hoc quae Г $\lambda$ $\kappa \nu े \sigma \varphi v \rho v o v$ habet

In dulces animae porrecta fronte legetis

Sic vobis totus dulcis hic Annus eat ${ }^{18}$.

In the period of humanism, it was recommended to the pupils early on to pay attention to the insignia and coats of arms of heroes. One of the lessons in the study of poetics was:

Let the pupils look at the insignia carefully, be attentive to the coats of arms of the heroes, and let them try to learn using anagrams thoroughly. Furthermore, let them endeavour to guess the point of riddles and puns and try to imitate the authors of poems and epigrams ${ }^{19}$.

16 J. Minárik, Renesančná a humanistická literatúra. Svetová, česká, slovenská, Bratislava 1985, p. 137.

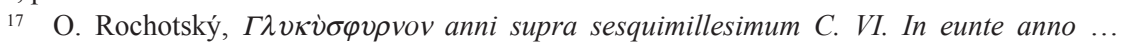
mecaenatibus Strenae Loco Oblatum Ab..., [S.1.: s.n., 1607], [28] unnumbered p., 4º, WUL, sign. BU 395684.

18 Ibid.

19 J. Rezik, S. Matthaeides, Gymnaziológia. Dejiny gymnázii na Slovensku, Bratislava 1971, p. 53 . 
The insignia of noble personalities had often been a theme in poetry and have a separate part in $Г \lambda v \kappa \dot{v} \sigma \varphi v \rho v o v$. Under a summarizing title illustri $[u m]$... virorum Rochotsky publishes verses about the insignia of Moravian nobility, and this adds to the devotional poems in the first part of the collection

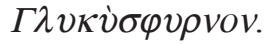

The authors had an inner feeling to jointly work on improving the literature, but they also understood the need for the writer to connect with his readers - equally the unknown readers they addressed in the prefaces, as well as the patrons whom they dedicated the books to. They reminded us that artistry grows with recognition. O. Rochotsky tried to curry favour of leading Moravian nobles, which is seen both in his encomia and in various smaller pieces of poetry devoted directly to certain patrons. Encomia celebrate benefactors, rulers, and poets. Their subject, however, was often shared with other genres of occasional poetry. They also frequently have the form of poetry of praise, or have religious and educational content ${ }^{20}$.

After an introductory dedication poem (eight couplets) in which the Baron of Liechtenstein is referred to as the cause of the restored peace in Moravia, Rochotský wished him a happy future and dedicated him the following poems. The main part of the print is formed by the poem Encomion pacis... In 135 couplets, the author celebrates the return of peace to Moravia after several years, during which the country suffered under hostile raids from the Hajduks and the Tatars. They burned the surroundings of Uherský Brod, and plundered Srážnica and Zlín. Many people have been dragged off. Later on, deadly diseases appeared ${ }^{21}$. Added to the poem is the emblem of the Lords of Liechtenstein. Rochotský continues to illustrate the antiquity of this noble name in three couplets. The coat of arms is decorated with an imperial crown as a special sign of the sovereign's favour. The red and gold colour mean freedom, stability, grandeur, but also courage and bravery.

Then vigorous attacks against the opponents of poets and humanist educa-

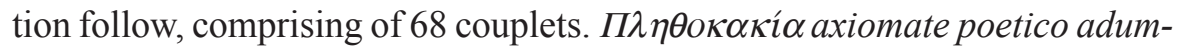
brata: Sunt Mulae Musae nostraque fama fames. In the chorus of this poem, the author continues to return to the theme already recalled in his previous prints - the adversity and hardship that scholars face constantly throughout their life. Although it is not explicitly stated, the first verses in Mille vafrae plebis scommata, mille minae (fol. Biiib) suggest that stereotypically and traditionally the instigator of the adversities is the uneducated public - vulgus iners, also represented with animal metaphors (the public have a wolf's mouth etc.). The poet attacks the idleness, the luxury and insensitivity whilst stating

\footnotetext{
20 J. Minárik, Renesančná a humanistická literatúra..., p. 139.

21 A. Truhlár̆, K. Hrdina, Rukovět' k písemnictvi humanistickému..., p. 335.
} 
the necessity of proper education and work (not just hollow talk). Schools should also be supported to regain order in society and in governing the municipalities on all levels, including the law and especially the church. His rhetorical aggression also turns to women wanting to marry uneducated men „«Et procul (inclamat) procul o procul este puellae / Queis mens simplicibus nubere velle viris / Hinc vafra Penelope, pellax hinc Gellia caedat / Hinc falli prona, hinc credula Phyllis eat» (fol. Biiib)"'22.

The twelve couplets in his poem Ad Joannem Zialkowsky a Zialkowicz... praise the diligence and perseverance of this Moravian grammarian, philologist and court poet. Jan Žalkovský from Žalkovice (five couplets) has an oak tree in his coat of arms, which is a sign of loyalty, strength, and endurance. The heirs of his family bring glory to the Emperor and the Emperor's Court.

Another one of his short poems (six couplets) called Ad ... Sigismundum Onessium a Brzezovic is also a dedication in which the author wishes a happy new year to the excellent supporter of literature, Zigmund Oneš from Březovice. Here the two faces of the ancient god Janus are an allegory marking the malice of last year leaving, whilst expressing hope and pleading for the coming year to be happier. $Z$. Oneš (two and three couplets) had probably remarkable fighting spirit, speed and alertness, but he was also wild and cunning - that's why his coat of arms features a lynx. His helmet adorned with a gilded diadem symbolizes his knightly honour.

The author didn't describe the emblem of the town Prostějov (two couplets), but he tells that it is an old town and an adornment of the state that the King and the Blessed Trinity favour. In nine couplets dedicated to the town - Ad Prostannam urbem, the author notes that the town of Uherský Brod suffered worse misfortunes of war, plague and death than Prostějov and reminds Prostějov of its duty to God. Similar in character are seven couplets $\mathrm{Ad} \mathrm{Pau-}$ lum Primum a Zwirzetina, reip. patriae civem litteratum. Pavol Primus (four and three couplets) also has a royal helmet decorated with a diadem, where the jewel is a wing. It signifies a joyous message, the flourish and growth of the lineage that can only be sustained by the commendable acts of its offspring. The creed this nobleman lived by is formed in a figurative, metaphorical couplet. He lives in God, and he will always praise Him. His relatives died in Uherský Brod and Rochotsky's guardian Peter Berger, the local pastor, died there as well. Two other members of the Berger family from Grinberg also lost their lives there. In this poem, the author expresses a friendly relationship

22 L. Strochová, Paupertate styloque connecti. Formální diskursivní modus, literární pole a textové utvářeni humanistické učenecké komunity v českých zemích. Disertační práce, Fakulta humanitních studií Univerzity Karlovy 2008, p. 198-199, [online] https://pytlivre.files.wordpress. com/2018/01/utvareni-humanisticke-ucenecke-komunity-v-ceskych-zemich-paupertate-styloque-connecti.pdf [accessed 11.04.2018]. 
with the family of his guardian from Slovakia; he speaks of the Bergers as his relatives. It seems that the relationship with the Berger family of Grinberg played a rather significant role in O. Rochotsky's life. He probably knew the members of the family from the times of his studies in Slovakia. An important evidence of this closeness is a poem - seven couplets by Eliáš Berger Arma Andrea Rochtii and Rochitzerperga describing the coat of arms of O. Rochotský with the dedication „Posonio Honoris et amoris ergo deproperabat Elias Bergerus a Grinberg, Poeta Hysto Hun. C.". This poem is not only a simple description of Rochotsky's coat of arms, but also an insight into his personality depicted in the coat of arms. O. Rochotsky had four colours in his coat of arms: white with black symbolizing restraint and modesty, along with gold also symbolizing honour and long life. The blue represents composure, prudence, soberness, and earnestness. Double crown with wings spread wide and a laurel standing for artists and scholars are used for decoration.

The original insignia with two silver salmons was amended by the Count of Salm (probably Nicolas IV, Julius I or Julius II from Salm-Neuburg) with the mythical red bird griffin during a solemn mass at the beginning of 1607. Rochotský in six couplets recounts important event of the members of one of the two main branches of the Salm-Neuburg family (the so-called Upper Salms). They originally ruled in Lorraine, obtained Czech nationality during the reign of king Maximilian II and then Rudolph II Habsburg in 1575 and 1576 , moved to Moravia and gained some Moravian manors ${ }^{23}$. The mythical beast combines the attributes of an eagle and a lion - wit and strength. It also symbolizes wisdom and vigilance. The author reminds members of this family to continue to live respecting God and emperor Rudolph whilst mentioning his past success in war. One of the members of this family - Count Nicolas of Salm (around 1522-1550) was also known in the Slovak region from the song about Muráň Chateau, where the fighting spirit of the Spanish mercenaries under king Ferdinand I is celebrated under the leadership of this count against the robber knights in Muráň 24 .

Many men in Rochotsky's scholarly circles, with whom he was probably in close contacts, were also teachers. He probably had a personal relationship with his colleague Jan Žabonius, who was a teacher at St. Henry's school in Prague since 1575. In the collection Г $\lambda$ um virorum, published in 1607 he adds verses dedicated to this nobleman. The insignia of J. Žabonius from Vyšetín (a total of four couplets) is a dropped ostrich feather symbolizing knight's pride and bravery. The author highlights

23 Salm-Neuburgové na Malé Hané, [online] http://www.jaromerice.cz/clanky/salm-neuburgove-na-male-hane-286.html [accessed 11.04.2018].

24 J. Minárik, Renesančná a humanistická literatúra..., p. 141. 
the generous nature of this nobleman and calls Žabonius a poet and a scholar, obliges him to serve the country and the public interest, hoping him to live a long life and die in righteousness.

Another poem In natalem Thomae Zvolensky, civi et senatori reip. Prostan (eight couplets) is congratulating the birthday of Thomas Zvolenský, a citizen and senator of the town of Prostějov. Rochotský appeals to the Holy Trinity to give T. Zvolenský a strong mind, health, the ability to recognize what is beneficial, enjoyable life, and good death. This is part of the collection

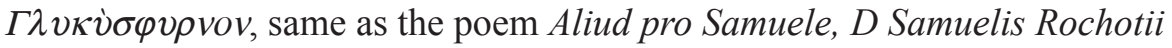
a Rochiczerberga, germani mei, filiolo recens nato, which similarly to genethlia lyric celebrates the birth - in this case the birth of Rochotsky's close relative Samuel. The poet calls the baby son the father's hope and wishes him good health and all good things given by God (three couplets and an eteostich). It should be emphasized, however, that this chronostich is not about Rochotsky's son Samuel, who was not born until June 1st, 1614. This is supported by the seven congratulatory couplets by Martin Rochotsky about the birth of Samuel, the son of his nephew O. Rochotsky In diem. D. Kal. Junii. The poem is dated in Bratislava and is attached to the print Poemativm De Peste... (Prague 1614) ${ }^{25}$, which is also not part of the Wrocław funds. The chronogram, included in the collection $Г \lambda v \kappa \dot{v} \sigma \varphi v \rho v o v$ commemorates the birth of another Samuel, who was the son of Rochotsky's relative and was probably born on December $6^{\text {th }}, 1606$.

Greeting poems - prosphoneses, were often aimed at sovereigns and patrons. Some of O. Rochotsky's poems had this already in their title. Their character was similar to that of encomia. One of the last poems of this col-

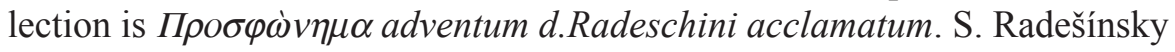
was another nobleman who significantly influenced the life of O. Rochotský. Eight couplets in the poetry collection $\Gamma \lambda \nu \kappa \dot{v} \sigma \varphi v \rho v o v$ express that the best protection against injustice is the favour of S. Radešínský (also towards the author). In Rochotsky's body of work there are several lyrical poems connected with this personality. At Charles University it was customary to publish congratulatory almanacs graduation. With their conventional content, full of ancient motifs, various allegories and personifications, as well as reflections on the importance of studies, the position of scholars in society and their dignity and usefulness, these poems mirror the degree of penetration of humanist culture into the circles of intelligentsia and they are becoming one

25 O. Rochotský, Poemativm De Peste ... Acceserunt eiusdem et amicorum Carminia Consolatoria Ad ... Carolum à Zierotina, in Rosicz etc. Dominum, Sac. Caes. Mai. a Concilijs nec non Marchionatus Moraviae Gubernatorem. Super Obitu Generi Baronis à Wrben. Jtem ... baronis à Zastrzissel. B. à Smirzicz, pié in ipso flore iuventae denatorum..., Pragae: [Typis Matthiae Pardubiceni, 1614], [20] unnumbered p., 4º. 
of the manifestations of education ${ }^{26}$. The collection In Obitvm ... Samvelis Radeschini... dedicated to the memory of the deceased lawyer S. Radešínský (Prague 1609) ${ }^{27}$, which is not a part of the Wrocław collection, is similar in nature. Its content is indicated on the title page - congratulations of friends after Rochotsky's placement in the office of the royal notary public. In addition to the votive verses from Rochotský himself or his friends, expressing human bonds and relationships of Rochotský, this collection comprised several lyrical songs related to this particular event from the author's life being named notary public. Here we shall mention only those that are at the same time connected to the personality of S. Radešínský. For example in the poem Ad comitem ante actum creationis (six couplets) the author states that S. Radešínský deserves the highest praise for being an experienced lawyer, guide and educator to O. Rochotský while he was on his way to achieve the legal rank. Magister J. Campanus Vodňanský, who contributed dedication poems to several of Rochotsky's works, reminds O. Rochotsky in seven couplets of Radesinsky's support that he should be thankful for and wishes Rochotský that the multitude of work be his encouragement and fame be a reward for the work done.

In epicedia, one meditates on the human transience and the necessity of death. Panegyrization of the deceased and expressing the grief over one's dead is very frequent. The main topic of the collection of poems In Obitvm ... Samvelis Radeschini... is an epicedium with the same title, where the author in 48 couplets celebrates the legal reputation of the deceased S. Radešínský, whom he met during his work in Prostějov in 1607-1608. S. Radešínský as a literary active nobleman and the imperial count palatine promoted O. Rochotský to a notary public, awarded him the title of ,poet laureate” and the aristocratic epithet - from Rochicerperk. The character of an epicedium or rather a condolence verse with a distinct panegyric element can be found in yet another poem by O. Rochotský Ad piissime defunctum fratrem Zachariam Radessinsky, that is also part of the collection dedicated to S. Radešínský. This „epic” as the author himself calls the composition, has the extent of ten couplets and depicts the sorrow over the deceased brother of the lawyer S. Radešínský.

\footnotetext{
E. Frimmová, Daniel Basilius (1585-1628). Život a dielo, Bratislava 1997, p. 89.

O. Rochotský, In Obitvm Illvstris. ... : Samvelis Radeschini à Radessovicz, in Rosineka etc. Sac. Caes. Mai. Consiliarij ... tanquam Regis B[o]emiae Camerae Procuratoris, nec non Iuris et aequarum Legum Doctoris ... Sacri Lateranensis Palatij Aulaeq[ue] Imperialis Consistorij Comitis, Aurati et Armatae Militiae Equitis etc. immatura morte Pragae prid. Cal. Maij ... [1609] sublati Sacrae Memoriae Carmen Epimikton ... Accesserunt eiusdem et amicorum gratulatoria. Super actu ab eodem Comite in fascium Notarij publ. largitione instituto, etc. ..., [Pragae]: Typis Schumanianis, [1609], [16] unnumbered p., $8^{\circ}$.
} 
The period when the renaissance and humanist culture started ebbing is also called the period of literary mannerism ${ }^{28}$. It is a period of transition from humanist to baroque literature. Depending on various factors, the developments in literary culture and aesthetic views in European countries were uneven. Somewhere we can see traces of renaissance mannerism, in other places the mannerism has more baroque feature ${ }^{29}$. In our environment, mannerism is dated around the turn of the $17^{\text {th }}$ century. The literature of this period has become more intellectual and elitist. Poetry was considered to be an exclusive creation for a small circle of scholars and displayed the author's fanciful fantasy $^{30}$. It was often overly artificial, decorative, and stylized. The lyric is characterized by the desire for independence, originality and novelty, protesting against the rules, eccentric and leading the authors to distance themselves from classical art disciplines and inclined to only formal experiments, perfectionism and ostentatious boasting with their artistic mastery. Typical were refined stylization and a perfect verse, wordplay and unusual themes ${ }^{31}$. Although Rochotsky's style of poetry is fairly classical and his artistic process steady, the poem Pro fuga stulserii votum from $Г \lambda v \kappa v ่ \sigma \varphi v \rho v o v$ can be considered as his manifestation of mannerism. He skilfully plays with words within the five couplets and urges to remove stupidity. This poem truly reflects the poet's lyrical wit and uses depictions, symbols and relations where each word starts with the letters:

Stulserius sua spurca serat stribilignia scabre

Stulta spuatque suae scommata Saevitiae:

Scurrilis sentina strophae, scabra schemata sumet

Sveta superbiscam stringere Saevitiam.

Surcule sancte sacram sate surcule stripe, spuentis:

Spurca sycophantae stringe Susurra soni.

Stulcserijque strophas scurilles siste, subinde

secaedat sacro saeva, Severa, sinu

Suppediter sorti solaria sacra sinistrae

Sit sopita Solo, sitque Sepulta Salo ${ }^{32}$.

Another part of Wrocław's volume is Rochotsky's first work Schimson seu Paraphrasis Poetica Eivsdem... ${ }^{33}$, published in Prague for the new year 1606.

28 J. Minárik, Renesančná a humanistická literatúra ..., p. 52.

29 Stownik literatury staropolskiej. Średniowiecze - renesans - barok, ed. T. Michałowska, B. Otwinowska, E. Sarnowska-Temeriusz, Wrocław-Warszawa-Kraków, p. 513.

30 J. Minárik, Renesančná a humanistická literatúra..., p. 19.

31 Stownik literatury staropolskiej..., pp. 515-516.

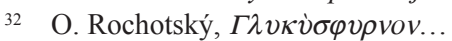

33 Idem, Schimson seu Paraphrasis Poetica Eivsdem. Avgvstissimo ... Romano[rum] ... Imperatori Rvdolpho II. Hvngarice, Boemice ... Regi ... D. D. clementissimo, in Auspicium, faelix novi Anni ChrIstIanI DiMInII [1606] consecrata et concinanta..., Pragæ: Typis Schumanianis, [1606], 
It is a reflection of the events of the past year in which the Turkish troops raided Moravia again ${ }^{34}$, plundered and ravaged a large part of the territory, and many towns became engulfed with plague. At the same time, however, it is an image of the autor's inner state of mind when his personal achievements are redeemed by the difficulties and worries of the ordinary life of a teacher at a town school where freshly after the official nomination for the imperial representative poet, he is faced with malice. Usual and necessary for the time would be expressing respect towards the ruler. This print therefore contains 17 couplets dedicated to the emperor Rudolph II as an appreciation for naming Rochotský the ,poet laureate” - or at least the author was given the tile in the name of emperor Rudolph $\mathrm{II}^{35}$.

Another poetic form oriented on the benefactor would be epithalamia focusing in particular on the marriage and the celebration of the newlyweds from aristocratic families. Rochotsky included these in his two collections. The collection Thalami arte et Marte illustriss. heroum... published in Prague in the year 1607 (hereinafter referred to as Thalami arte et Mar$t e)^{36}$ contains epithalamia celebrating marriages of the kinship of Karel from Žerotin. The first epithalamium Perillustris [simi] ... herois ac d. d. Arclebi a Cunovicz (16 X 1607) was dedicated to the Moravian nobleman inclined to Protestantism, Archleb from Kunovice and the second - Thalami herois ... d. d. Bohuslavi Prakschicky a Zastrizsel... (28 X 1607) was celebrating the marriage of B. Prakšický from Zástřizl with Helena, the daughter of Caspar from Žerotin. In the same category we find Epithalamium in Caroli l. b. a Zierotina ... sponsi et Annae Mariae a Waldstein, which is part of the collection mentioned above Poemativm De Peste... and Rochotsky dedicated it to his patron's Karel from Žerotin's fourth marriage with the widow Katarina from Waldstein, formerly married to the nobleman Smilo Osovský from Doubravice. The author or printer of this work probably made a mistake and confused the name Katarina in the title of the poem with Žerotin's previous wife Anna Maria from Waldstein. The right title then ought to be „Catherinae a Waldstein" 37 .

The WUL also owns a separate volume, in parchment binding marked by the signature BU 395681 - a historical epic consisting of 1570 hexameters

[36] unnumbered p., $4^{\circ}$, WUL, sign. BU 395685.

34 Turci na Moravě...

35 J.L. Flood, Poets laureate in the Holy Roman Empire. A bio-bibliographical handbook. Vol. 3: $L-R$, Berlin 2006, p. 1731.

36 O. Rochotský, Thalami arte et Marte, Illustriss. heroum ... consecrati novis sponsis ab Andreae Rochotio a Rochitzerberga ... gymnasii Prostannensis rectore, Pragae: typis Schumanianis..., 1607, [8] unnumbered p., 4º, WUL, sign. BU 395686.

37 A. Truhlář, K. Hrdina, Rukovět k písemnictví humanistickému..., p. 338. 
Actio Pacificatoria Hunno Austriaca... (Hungarian-Austrian Conciliation Act...) published in Prague in the year $1610^{38}$, in which the author describes the disputes between the Hungarian king Matthew II and the German emperor Rudolph II. These escalated to a war conflict, when Matthew II led a military expedition against his brother through Moravia towards Prague. Then the author commemorates the celebration of the Liben peace, which ended the disagreements between the Sovereigns. You'll find 12 couplets under the coat of arms of the Žerotin family in this print: In insignia Zierotiniana ad ... Carolum baron Zierotinum and another dedication: 81 iambic couplets called Arte et marte illustrissimo ... Carolo seniori, baroni a Zierotina. The name of this poem is similar to the Thalami arte et Marte... collection published in Prague in 1607.

Historical themes were also a point of interest to J. Campanus Vodňanský, a scholar and philologist who contributed recommendations to earlier works of Rochotsky and later drew on Czech history in his poem Cechias seu Bohemia Heneta... (1616). Thence his recommendation verses (nine couplets) can be found also on the title page of Rochotsky's historical epic Actio Pacificatoria Hunno Austriaca... Here, Campanus likens Rochotsky's work to ancient authors such as Homer, Hesiodos and Vergil. O. Rochotsky also published nine couplets in Campan's work Odarum Sacrarum ... Liber Posterior (Prague 1612). In addition to this epic there are two other prints of Rochotský in the WUL: the events described in the epic Actio Pacificatoria... are thematically followed by a 553 hexametric poem elaborately describing the coronation festivities of king Matthew II in Frankfurt; Pompa Inavgvrationis Et Coronationis Mathice II... ${ }^{39}$, published in Prague in 1612. King Matthew II was crowned the King of Hungary in 1608 with succession rights in Bohemia. He used the mental illness of his brother Rudolph II and the dissatisfaction of the Czech estates with Rudolph's governing, and in 1611 he gained the Czech crown. Since Rudolph II died shortly afterwards (30 I 1612), Matthew was crowned the Holy Roman and German emperor in Frankfurt on June $13^{\text {th }} 1612$ by the archbishop filling in for the Roman pope. The works Pompa Inavgvrationis... describing the coronation of the Emperor Matthew II similar to the previous poetic song Actio Pacificatoria ... are both dedicated to Rochotsky's most important patron Karel from Žerotín. Here we

38 O. Rochotský, Actio Pacificatoria Hunno Austriaca Cui Accesserunt Motus et Confaederatio Marchionatus Moravice, Item Expeditio in Boemiam et salva domum vorsoria nec non Mathice II Hungarorum Regis etc., sacra initiatio et coronatio, Regniq[ue]. eius administrandi providentia, [S.1.: s.n., 1609], [56] unnumbered p., 4, WUL, sign. BU 395681.

39 O. Rochotský, Pompa Inavgvrationis Et Coronationis Mathice II ... Hvngarice Et Boemice Regis, etc. in S. R. Impe. Regem et Casarem unanimi VII. virorum coelectorumq[ue] Imperij Romani consensu, Francofvrti Ad Moenvm. Redintegrata sancita et peracta Die IunI XIII. et XXIV. Anni [1612]..., Pragæ: Typis Ionatæ Bohutsky, [1612], [24] unnumbered p., 4º, WUL, sign. BU 352676. 
can also see the transmission of university literary practices to the field of noble patronage ${ }^{40}$. In Pompa ... the author celebrates in six couplets his benefactor and his support and confesses that all he shall write will be dedicated to him, whether it will be poetry or descriptions of real events: ,sive poesis erit, seu certa relatio, sive nescio quid melici, muneris omne tui est". He signs the work as „detissimus servus M. A. R. á R. B.” (the most devoted slave/ servant...). As an introduction to Pompa Inavgvrationis..., under the royal emblem the author also features the composition called Insignia imperatoria (ruler's insignia). They are two votive couplets, dedicated to the emperor Matthew II. Rochotsky attributes to Matthew the body of a lion and the mind of an eagle („leonis corpore, mente aquilae”), and wishes this victor over the Turks that his kingdom be flourishing under his rule. The poem is thematically related to the main part of the printed work, which describes the coronation festivities of king Matthew II in Frankfurt.

Congratulatory poems, which the authors used to express their loyalty to their supporters, most frequently on the occasion of the New Year, were called xenium poems. Although they originally had the form of shorter poems or epigrams, Rochotsky's xenium Ad Illvstrem ... Carolum Seniorem B. L. à Zieroti$n a \ldots$ (Prague 1617 ) ${ }^{41}$ ranges up to 86 hexameters. This poem dedicated to Karel from Žerotin recounts the disasters that humanity has been afflicted by in the last four years: natural elements, discord, wars, plague. Finally, Rochotský calls for moral resurgence and wishes good fortune to Karel ${ }^{42}$. At present, Xenium Calend [is] Januarii ... 160943, written by Rochotsky for Jan from Švamberk, is missing. One xenium - Pro Calendis Januariis votum (seven couplets) can also be found in the above-described poetry collection $Г \lambda v \kappa v \sigma \varphi v \rho v o v$. In the dedication for the first of January, the author asks God to end the evils of last year.

Not only the congratulatory poems, but also other small lyrical forms in O. Rochotsky's collections create a picture of the community of educated noblemen, burghers and teachers that was well known to the author, as well as the aristocrats whose favour he was trying to curry. The prints preserved in the WUL unfold a representative summary of Rochotsky's work and broadly document the author's relationships with both groups - benefactors and friends.

The importance of Rochotsky's prints preserved in the Wrocław's University Library lies in the fact that some of them - e.g. Iosephiados..., Gedeon...,

40 L. Strochová, Paupertate styloque connecti..., pp. 198-199.

41 O. Rochotský, Ad Illvstrem ... Carolum Seniorem B. L. à Zierotina, Sac. Caes. Maj. Consiliarium, Dominum in Rosicz, Przerow, Drzewohosticz, Trzebicz etc., Meccenatem ac Patronum optimé de se meritum. Xenia Calend. Ianvar. ... [1617] ..., Reginæ Hradecij cis Albim: Excudebat Martinus Kleinwechter, [1617]. 8 unnumbered p., 4, WUL, BU 567556.

42 A. Truhláŕ, K. Hrdina, Rukovět' k pisemnictvi humanistickému..., p. 338.

43 Ibidem, p. 336. 
Schimson..., Thalami arte et Marte..., Xenium Calend [is] Januarii ... 1609, and Actio Pacificatoria ... are unique (or in the catalogues are described but in reality unavailable), not available in libraries in Bohemia or Slovakia, and thus have great value both in the research of life and work by O. Rochotský, but also in the broader survey of the work of the Slovak humanists abroad.

\section{Appendix}

The prints that are part of WUL collections in chronological order according to year of publication:

Schimson seu Paraphrasis Poetica Eivsdem. Avgvstissimo ... Romano[rum] ... Imperatori Rvdolpho II. Hvngariæ, Boemiæ ... Regi ... D. D. clementissimo, in Auspicium, faelix novi Anni ChrIstIanI DiMInII [1606] consecrata et concinanta... / Authore, Andrea Rochotio... . - Pragæ: Typis Schumanianis, [1606]. - [36] unnumbered p., $4^{\circ}$.

Gedeon comedia nova. Cum primis ad usum scholasticum et conditionem temporum accomodata. - pro noVa ComaeDIa [1606] ... . - M. Iohan. Campanus Vodn.... / Andreae Rochotii a Rochicerberga... . - Pragae: typis Schumanianis..., [1606]. - [36] unnumbered p., $4^{\circ}$.

Iosephiados comaedia ex genesis Lib. Cap. 39., 40., 41 / Andreae Rochotii a Rochiczerberga. - Pragae: typis Schumanianis, [1607-1608]. - [44] unnumbered p., $4^{\circ}$.

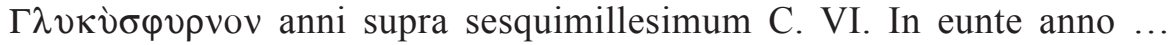
mecaenatibus Strenae Loco Oblatum / Ab Andrea Rochotio á Rochitzerberg... . - [S.1.: s.n., 1607]. $-[28]$ unnumbered p., $4^{\circ}$.

Ad Illvstrem ... Carolum Seniorem B. L. à Zierotina, Sac. Cæs. Maj. Consiliarium, Dominum in Rosicz, Przerow, Drzewohosticz, Trzebicz etc., Mecænatem ac Patronum optimé de se meritum. Xenia Calend. Ianvar. ... [1617] ... / M. Andreas Rochotius á Rochiczerperga, P. Cæs. nec. non. Not. publ. Imperialis, Civis Chrud . - Reginæ Hradecij cis Albim: Excudebat Martinus Kleinwechter, [1617]. - [8] unnumbered p., $4^{\circ}$.

Actio Pacificatoria Hunno Austriaca Cui Accesserunt Motus et Confæderatio Marchionatus Moraviæ, Item Expeditio in Boemiam et salva domum 
vorsoria nec non Mathiæ II Hungarorum Regis etc., sacra initiatio et coronatio, Regniq[ue]. eius administrandi providentia/ Andreae Rochotij á Rochiczerperga... - [S.1.: s.n., 1609] . - [56] unnumbered p., 4.

Pompa Inavgvrationis Et Coronationis Mathiæ II ... Hvngariæ Et Boemiæ Regis, etc. in S. R. Impe. Regem et Cæsarem unanimi VII. virorum coelectorumq[ue] Imperij Romani consensu, Francofvrti Ad Moenvm. Redintegrata sancita et peracta Die IunI XIII. et XXIV. Anni [1612]... / Authore M. Andrea Rochotio á Rochiczerperga... . - Pragæ: Typis Ionatæ Bohutsky, [1612]. - [24] unnumbered p., $4^{\circ}$.

Thalami arte et marte: Illustriss. heroum ... consecrati novis sponsis / ab Andreae Rochotio a Rochitzerberga ... gymnasii Prostannensis rectore. Pragae: typis Schumanianis..., 1607. - [8] unnumbered p., $4^{\circ}$.

\section{The prints that are not found in the Wroclaw University Library}

In Obitvm Illvstris. ... : Samvelis Radeschini à Radessovicz, in Rosineka etc. Sac. Caes. Mai. Consiliarij ... tanquam Regis B[o]emiae Camerae Procuratoris, nec non Iuris et aequarum Legum Doctoris ... Sacri Lateranensis Palatij Aulaeq[ue] Imperialis Consistorij Comitis, Aurati et Armatae Militiae Equitis etc. immatura[m] morte Pragae prid. Cal. Maij ... [1609] sublati Sacrae Memoriae Carmen Epimikton ... Accesserunt eiusdem et amicorum gratulatoria. Super actu ab eodem Comite in fascium Notarij publ. largitione instituto, etc. ... / Authore Andrea Rochotio à Rochiczerperga... . - [Pragae]:Typis Schumanianis, [1609]. - [16] unnumbered p., $8^{\circ}$.

Poemativm De Peste ... Acceserunt eiusdem et amicorum Carminia Consolatoria Ad ... Carolum à Zierotina, in Rosicz etc. Dominum, Sac. Caes. Mai. a Concilijs nec non Marchionatus Moraviae Gubernatorem. Super Obitu Generi Baronis à Wrben. Jtem ... baronis à Zastrzissel. B. à Smirzicz, pié in ipso flore iuventae denatorum... / M. Andreae Rochotii à Rochiczerperga... . - Pragae: [Typis Matthiae Pardubiceni, 1614]. - [20] unnumbered p., $4^{\circ}$. 


\section{Bibliography}

Biografický slovník Slezka a severní Moravy : nová řada. Sešit 1 [vol. 13], ed. M. Myška, L. Dokoupil, Ostrava 2000

Bůžek V., Literární mecenát nižši šlechty v predbělohorských Čechách, [in:] Husitství - reformace - renesance. Sbornik k 60. narozeninám Františka Šmahela, Praha 1994, pp. 830-843.

Daňhelka J. [and others], Dějiny české literatury. [Vol.] I, ed. J. Hrabák, Praha 1959.

Flood J.L., Poets laureate in the Holy Roman Empire. A bio-bibliographical handbook. Vol. 3: $L-R$, Berlin 2006.

Frimmová E., Daniel Basilius (1585-1628). Život a dielo, Bratislava 1997.

Horváth P., Humanisti z Českých krajín v pobelohorskom exile v Trenč́ne, „Historica” 1975, Vol. 26, pp. 155-168.

Minárik J., Renesančná a humanistická literatúra. Svetová, česká, slovenská, Bratislava 1985.

Pišna J., Předmluvy a paratexty $v$ českých tiscich druhé poloviny 16. století a jejich výzkum - poznámky k problematice, „Kniha” 2014, pp. 79-80.

Rezik J., Matthaeides S., Gymnaziológia. Dejiny gymnázii na Slovensku, Bratislava 1971.

Salm-Neuburgové na Malé Hané, [online] http://www.jaromerice.cz/clanky/salm-neuburgove-na-male-hane-286.html [accessed 11.04.2018].

Slovenský biografický slovník od roku 833 do roku 1990. Vol. 5: R-S, ed. V. Mináč, Martin 1992.

Stownik literatury staropolskiej. Średniowiecze - renesans - barok, ed. T. Michałowska, B. Otwinowska, E. Sarnowska-Temeriusz, Wrocław-Warszawa-Kraków 1998.

Strochová L., Paupertate styloque connecti. Formálni diskursivní modus, literární pole a textové utvářeni humanistické učenecké komunity v českých zemich. Disertační práce, Fakulta humanitních studií Univerzity Karlovy 2008, p. 198-199, [online] https://pytlivre.files.wordpress.com/2018/01/utvareni-humanisticke-ucenecke-komunity-v-ceskych-zemich-paupertate-styloque-connecti.pdf [accessed 11.04.2018].

Šimůnek R., Reprezentace české středověké šlechty, Praha 2013.

Škovierová A., Humanistický básnik Ondrej Rochotský. Jeho život, činnost', dielo a vzt'ahy ku Slovensku, „Kniha” 2007, pp. 223-233.

Škovierová A., Jesseniovi slovenski súčasnici v Čechách. Vzájomné vzt’ahy a kultúrne súvislosti, [in:] Ján Jessenius (1566-1621) Ludia a doba. Medzinárodná vedecká konferencia konaná 8. decembra 2016, ed. M. Gogola, L. Rybár, Bratislava 2017, Historia Medicinae Slovaca, 1, pp. 72-92.

Škovierová A., Ondrej Rochotský a jeho literárna činnost’v kontexte tvorby slovenských humanistov v Čechách, „Kniha” 2012, pp. 133-145.

Wintr Z., Život a učeni na partikulárnich školách v Čechách a XV. a XVI. století, Praha 1901.

Truhlář A., Hrdina K., Rukovět’ k pisemnictvi humanistickému, zvlášttě básníckému v Čechách a na Moravě ve XVI. století, Praha 1918.

Turci na Moravě a turecké války, [online] http://historik.webgarden.cz/rubriky/hlavni-stranka/turci-na-morave-a-turecke-valky [accessed 25.08.2016]. 